\title{
Communication
}

\section{The catalytic properties of DNA G-quadruplexes rely on their structural integrity}

\author{
Jielin Chen a,†, Mingpan Cheng a,†, Jiawei Wang a, Dehui Qiu a, David Monchaud ${ }^{\mathrm{b}}$, \\ Jean-Louis Mergny a,c, Huangxian Ju a, , Jun Zhou a,\# \\ a State Key Laboratory of Analytical Chemistry for Life Science, School of Chemistry and Chemical Engineering, Nanjing University, Nanjing 210023, \\ Jiangsu, China \\ ' Institut de Chimie Moléculaire, Université de Bourgogne (ICMUB), CNRS UMR6302, UBFC Dijon 21000, France \\ c Laboratoire d'Optique et Biosciences, Ecole Polytechnique, CNRS, INSERM, Institut Polytechnique de Paris, 91128 Palaiseau, France
}

\section{A R T I C L E I N F O}

\section{Article history:}

Received 10 October 2020

Accepted 11 November 2020

Available online 5 March 2021

\section{Keywords:}

G-quadruplex

G-quadruplex DNAzyme

G-vacancy

G-quartet integrity

Guanine surrogate

\begin{abstract}
A B S T R A C T
The influence of the G-quartet structural integrity on the catalytic activity of the G-quadruplex (G4) was investigated by comparing the G4-DNAzyme performances of a series of G4s with a G-vacancy site and a G-triplex (G-tri). The results presented herein not only confirm that the structural integrity of the 3'-end G-quartet is necessary for G4s to be catalytically competent but also show how to remediate G-vacancy-mediated catalytic activity losses via the addition of guanine surrogates in an approach referred to as G-vacancy complementation strategy that is applicable to parallel G4s only. Furthermore, this study demonstrates that the terminal G-quartet could act as a proximal coordinating group and cooperate with the flanking nucleotide to activate the hemin cofactor.
\end{abstract}

(C) 2021, Dalian Institute of Chemical Physics, Chinese Academy of Sciences. Published by Elsevier B.V. All rights reserved.
Since Breaker and Joyce discovered DNAzymes [1], catalytic nucleic acids have gained special attention [2-4] thanks to their designability, versatility, and biocompatibility, which make them efficient biodevices in various fields, including chemical transformations [5,6], biosensing [7,8], and chemical biology [9]. An important biocatalytic system is the G-quadruplex (G4) DNAzyme, which results from the non-covalent association of G4s and the hemoprotein cofactor hemin. G4-DNAzymes show controllable catalytic properties (notably via the selection of the DNA sequence the G4 folds from) and a wide substrate scope [10-13]. Recently, numerous strategies have been devised to improve the activity of G4-DNAzymes and gain insights into their intrinsic catalytic mechanism, including the addition of external boosters [14-17] and fine-tuned sequences [18-25].

Beyond these efforts, little is known about how the external G-quartet, which interacts with hemin and is important in the catalysis process, affects the G4-DNAzyme properties of the G4 it belongs to. In previous studies [12,26,27], Sen and colleagues proposed a catalytic model in which the catalytic intermediate was a hexacoordinated hemin iron, on the basis of both UV-Vis [12] and electron paramagnetic resonance (EPR) spectroscopy [27]. Yamamoto et al. [28,29] applied vibrational and nuclear magnetic resonance (NMR) spectroscopies to further investigate the coordination state of the hemin iron. These studies

\footnotetext{
* Corresponding author. E-mail: hxju@nju.edu.cn

\# Corresponding author. E-mail: jun.zhou@nju.edu.cn

+ These authors contributed equally to this work.

This work was supported by the National Natural Science Foundation of China (21977045, 21635005), Fundamental Research Funds for the Central Universities (02051430210), the Funds of Nanjing University (020514912216).

DOI: 10.1016/S1872-2067(20)63744-5 | http://www.sciencedirect.com/journal/chinese-journal-of-catalysis | Chin. J. Catal., Vol. 42, No. 7, July 2021
} 
Table 1

DNA sequences used in this study.

\begin{tabular}{lc}
\hline Name & Sequences $\left(5^{\prime}-3^{\prime}\right)$ \\
\hline GV1 & TT GTG T GGG T GGG T GGG T \\
GV2 & TT GG T GGG T GGG T GGG T \\
GV2A & TT GG T GGG T GGG T GGG A \\
GV2TC & TT GG T GGG T GGG T GGG TC \\
PG4 & TT GGG T GGG T GGG T GGG T \\
G4A & TT GGG T GGG T GGG T GGG A \\
G4TC & TT GGG T GGG T GGG T GGG TC \\
G-Tri & TT GGG T GGG T GGG \\
TG3T & T GGG T \\
\hline
\end{tabular}

concurred with a double role of the external G-quartet of the $\mathrm{G} 4$, behaving as both a hemin-binding site via $\pi-\pi$ stacking interactions and a hemin activator by providing a proximal ligand (e.g., through G-flipping) that completed the coordination sphere of the iron atom (the sixth coordinate being the stochiometric oxidant $\mathrm{H}_{2} \mathrm{O}_{2}$ ) [27,30-33].

To further investigate whether a guanine could actually coordinate bound hemin and how the structural integrity of the external G-quartet of a G4 could influence its catalytic properties, we implemented a strategy based on G-vacancy (GV) sites. To date, only three GV structures have been elucidated [34-36]. We selected two GV structures (GV1 and GV2) described by Phan et al. $[34,36]$ as starting models (sequences are shown in Table 1). Our strategy, which is schematically depicted in Fig. 1, relies either on the study of GVs in interaction with guanine surrogates [guanosine $(G)$ or acycloguanosine, also known as acyclovir (A)] or that of a G-triplex (G-Tri) in interaction with a TG3T strand in order to restore a complete 3 '-end external G-quartet (the privileged hemin-binding site) [18,37] in a controlled manner.

We first analyzed the G4 folding of both GV1 and GV2 using circular dichroism (CD) spectroscopy. The obtained CD signatures (a negative peak at approximately $245 \mathrm{~nm}$, a positive

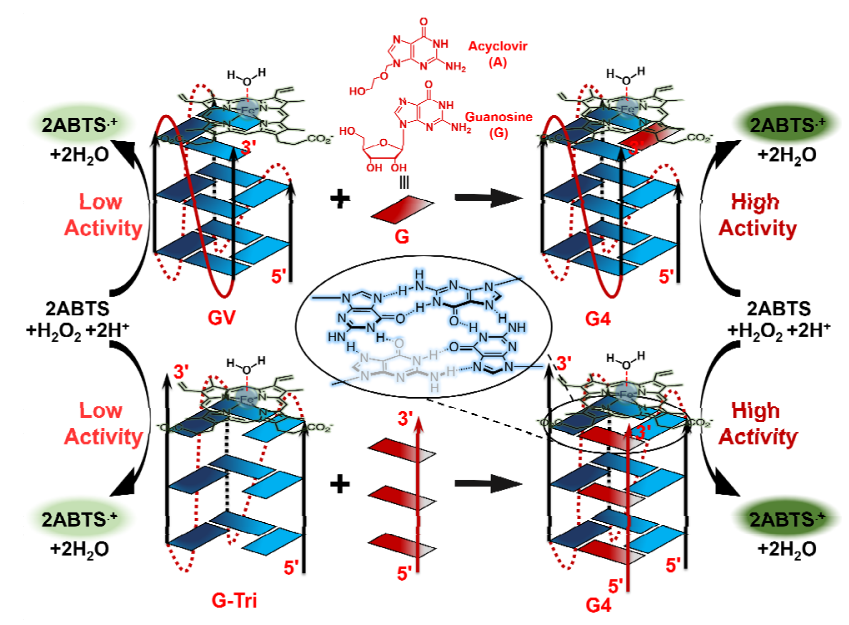

Fig. 1. Schematic representation of the influence of the G-quartet integrity on the G4-DNAzyme activity. Upper panel: G4 with a G-vacancy site (GV) (structure of GV2 is shown here, PDB ID is 6K3X) can be completed by the free guanine surrogates [(acyclovir $(A)$ and guanosine $(G)$ ]. Lower panel: the G-quartet integrity of a G-triplex (G-Tri) was restored with the single-stranded G-rich sequence TG3T. peak at approximately $265 \mathrm{~nm}$, Fig. S1) confirmed the G4 folds and indicated that both were parallel G4s, as previously demonstrated [35,36,38-40]. Noteworthily, the intensity of the positive peak at approximately $265 \mathrm{~nm}$ for GV1 and GV2 was slightly lower than that for an intact 3-quartet parallel G4 (PG4) as a result of the G-vacancy. Next, the catalytic properties of GVs and their G/A partners were assessed via the classical ABTS oxidation reaction (Fig. 2). Reaction rates obtained with GV1 and GV2 (11.7 and $31.7 \mathrm{nM} / \mathrm{s}$, respectively) were lower than that of the structurally intact G4 (PG4, $59.9 \mathrm{nM} / \mathrm{s}$, that is, 5.1 and 1.9-fold higher than that of GV1 and GV2, respectively, Fig. 2(b)). These results indicated that the structural disruption of the external G-quartet strongly impacted the G4-DNAzyme activity.

Recent reports $[35,36,38]$ show that guanine derivatives such as acyclovir (A) and guanosine (G) have considerable affinities toward GVs and are excellent candidates as GV fillers (Fig. 2(a)). Here, an increasing concentration of A/G (between 2 and 100 mol equiv.) gradually improved the catalytic activity of $\mathrm{GVs}$, and reached a plateau at $[\mathrm{A}] /[\mathrm{GVs}]=20$, once the majority of vacancies in GV were filled by A/G (Figs. 2(c,d), S2, and S3). In addition, the final activity of GV1 + A/G was not completely restored compared to that of PG4 (Fig. 2(c)), which might be due to the thymine bulge (left panel in Fig. 2(a)). Furthermore, CD spectra (Fig. S1) and UV-melting data (Fig. S4) for GVs with guanine derivatives proved that the addition of GV fillers enhanced the stability of G4s. Control experiments performed with A/G without GVs or with PG4 (Fig. S3) confirmed that they did not influence the catalysis alone. Altogether, these results confirmed that restoring the structural integrity of the 3 -end G-quartet positively impacted the catalytic properties of resulting G4s, without fully reaching that of the intact PG4.

Next, we sought to compensate for GV-mediated catalytic activity losses by adding flanking nucleotides (dA and dTC, referred to as GV2A and GV2TC, respectively) on the $3^{\prime}$ end of the GV2, known to promote the catalytic reaction by coordinating iron-bound $\mathrm{H}_{2} \mathrm{O}_{2}$ [21]. CD spectra of GV2A and GV2TC were similar to those of GV1 and GV2, with a slightly lower peak intensity compared to the intact G4s (G4A and G4TC, Fig. S1(a)). GV2 with either a flanking dA (GV2A) or dTC (GV2TC) increased the DNAzyme activity of GVs (Fig. 2(b)). dA increased the activity of GV2 from 31.7 to $108.1 \mathrm{nM} / \mathrm{s}$, while dTC increased it up to $231.4 \mathrm{nM} / \mathrm{s}$. However, their catalytic activities were still lower than those of the corresponding intact G4s, that is, G4A (234.0 nM/s) and G4TC (489.0 nM/s), respectively. The addition of $A / G$ was investigated and was found to restore the DNAzyme properties in a dose-dependent manner (Figs. 2(e,f)) up to $201.9,198.4,412.6$, and $447.5 \mathrm{nM} / \mathrm{s}$ for the GV2A + A, GV2A + G, GV2TC + A, and GV2TC + G systems, respectively. These catalytic properties remained lower than those of the corresponding intact G4s, that is, G4A and G4TC, respectively.

Additionally, we designed a different system, a G-triplex (G-Tri) with incomplete G-quartets at both extremities, whose structural integrity was restored through the addition of a G-rich single strand (TG3T, d[TGGGT]) to form a $(3+1)$ composite G4 in $\mathrm{Na}^{+}$buffer $[41,42]$ (Fig. S1(C)). The catalytic activity of the G-Tri + TG3T system increased with increasing con- 
(a)
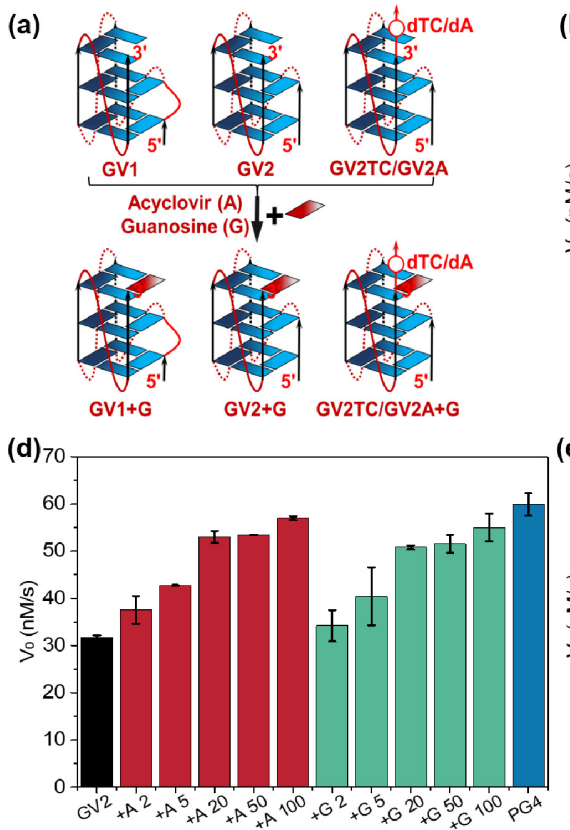

(b)
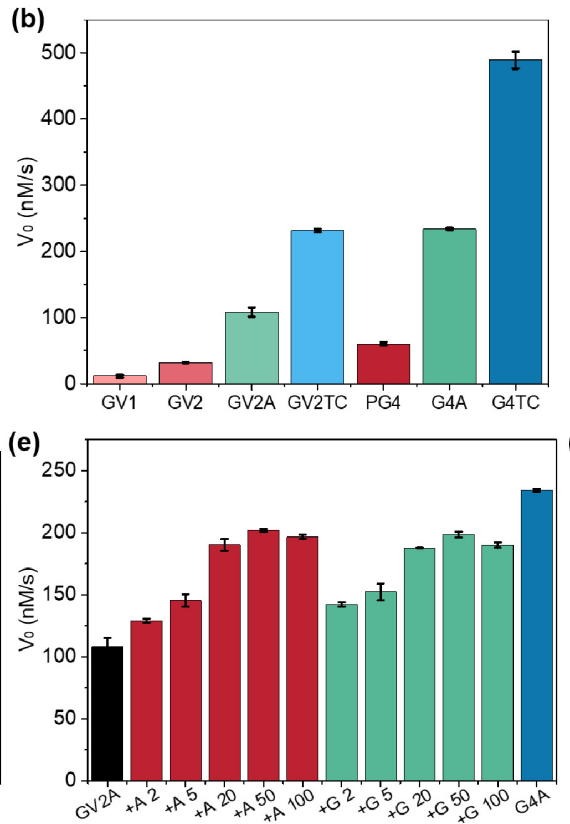

(c) 70
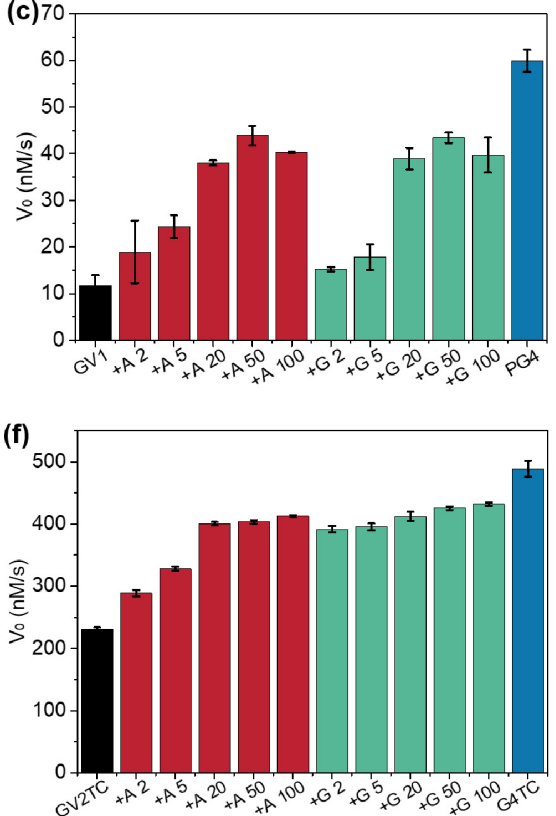

Fig. 2. (a) G-vacancy complementation strategy with free guanine surrogates. G4-DNAzyme activity of (b) GVs and G4s, and (c) GV1, (d) GV2, (e) GV2A and (f) GV2TC upon addition of increasing concentrations (2, 5, 20, 50, and 100 mol. equiv.) of guanine surrogates [acyclovir (A) and guanosine (G)].

centrations of TG3T, from 19.7 (without TG3T) to $50.4 \mathrm{nM} / \mathrm{s}$, reaching levels comparable to the activity of the intact PG4 (53.2 nM/s, Fig. 3). Control experiments performed without G-Tri confirmed that TG3T did not influence the catalysis alone (Fig. S3).

In all the above experiments, the G4s used were parallel G4s only. We decided to assess whether the GV complementation strategy would be applicable to antiparallel G4s as well. Thus, we constrained G4s through a Holliday junction (HJ)-based approach described by Marguiles et al. [43]. As depicted in Figs. S5(a) and 4(a), a wide selection of dsDNA sequences (Table S1) led to the formation of an $\mathrm{HJ}$ that uniquely allowed for fully controlling the polarity of the G4-forming strands and the whole G4 structure after hybridization. We designed two HJ-constrained antiparallel G4s with GV sites on either $3^{\prime}$ - or $5^{\prime}$-end (HGV1 and HGV2, respectively) and two HGVs with dTC flanking nucleotides on either $3^{\prime}$ - or $5^{\prime}$-end (HGV1TC and

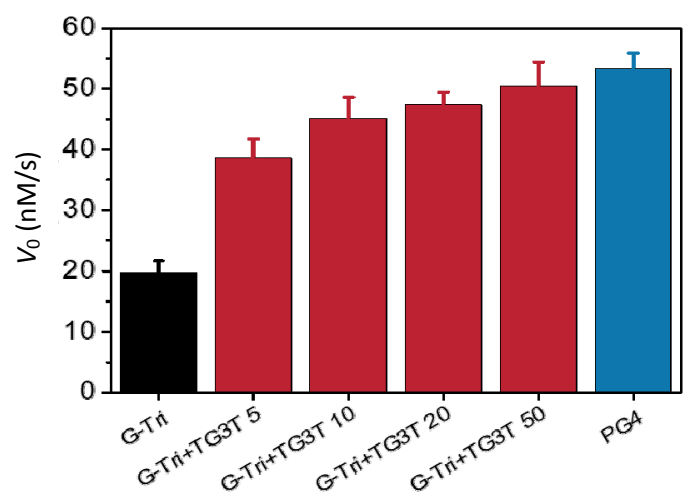

Fig. 3. G4-DNAzyme activity of G-triplex (G-Tri) upon addition of increasing concentrations $(5,10,20$, and 50 mol equiv.) of TG3T.
HGV2TC, respectively), along with the control constructs in which the external G-quartet was complete (HG4, HG4TC-1 and HG4TC-2) (Fig. 4(a)). The secondary structures of all these constructs were verified using isothermal difference spectrum (IDS) and CD (Fig. S5). As observed in Fig. 4(b), HGVs without flanking dTC exhibited low catalytic competences, with a rate of 39.0 and $44.2 \mathrm{nM} / \mathrm{s}$ for HGV1 and HGV2, respectively, vs 75.4
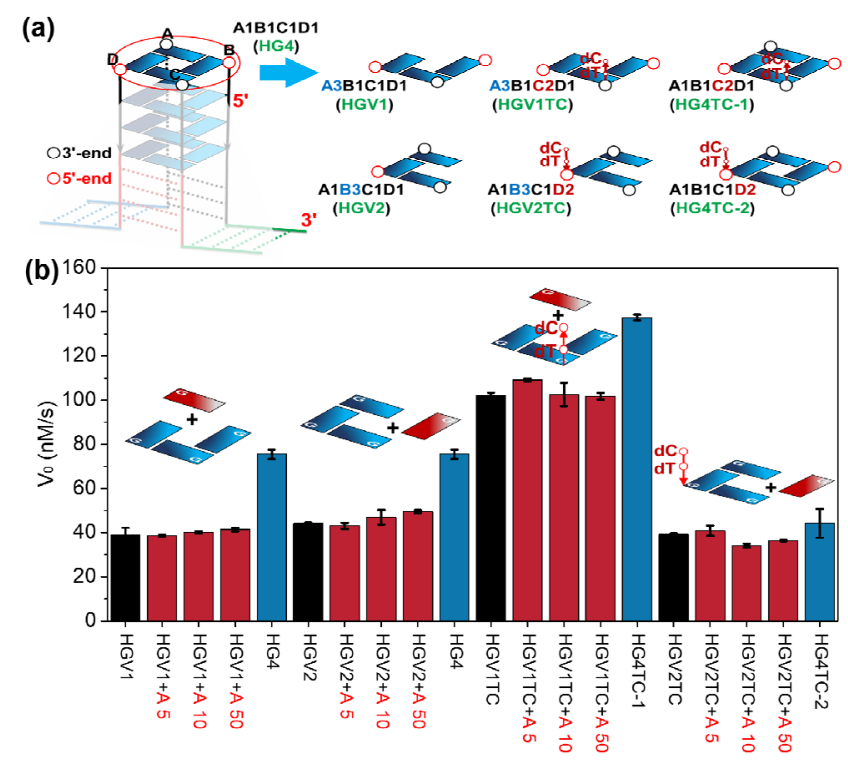

Fig. 4. Catalytic performances of Holliday junction-constrained G4s: (a) Schematic representation of the seven different Holliday junction-induced G4 systems (HGV and HG4): with (HG4, HG4TC-1, and HG4TC-2) or without (HGV1, HGV1TC, HGV2, and HGV2TC) intact G-quartet, and some of them with flanking dTC (HGV1TC, HGV2TC, HG4TC-1, and HG4TC-2). (b) The G4-DNAzyme activity of GVs upon addition of increasing concentrations of acyclovir (A). 


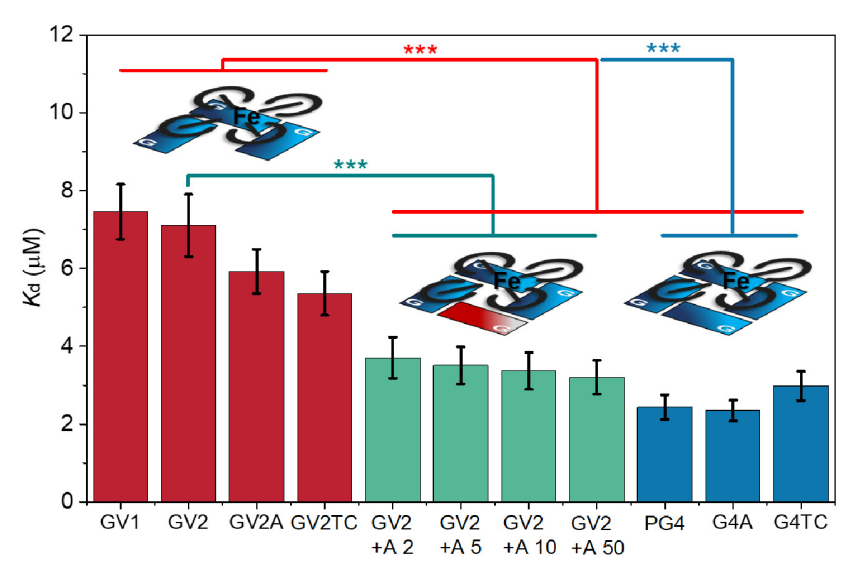

Fig. 5. Dissociation constants $\left(K_{\mathrm{d}}\right)$ between hemin and GVs (red bars), GVs upon addition of increasing concentrations of acyclovir (A) (green bars), and intact G4s (blue bars). Student's $t$-tests were performed between intact G4s and GVs (containing GV2 integrated with acyclovir): $* * *$ means $p<0.001$, i.e. the difference between each group data set is very significant.

$\mathrm{nM} / \mathrm{s}$ for the complete G4 (HG4). Interestingly, the performance of HG4 was enhanced by the presence of the terminal dTC on its $3^{\prime}$-end (HG4TC-1) and decreased when on its $5^{\prime}$-end (HG4TC-2). Regarding HGVs, the presence of a vacancy site at both 3 '- and $5^{\prime}$-ends was detrimental to the activity of the corresponding G4s, and the addition of increasing concentrations of acyclovir (A) (according to the protocol described above) had no effects on the activity of HGVs. These results indicate that the G-vacancy complementation strategy is effective only when applied to parallel G4s.

To gain further insight into how the structural integrity of G-quartet affected the catalytic performances of the G4s they belonged to, thermal stability experiments were conducted. We found that the presence of GV sites decreased the melting temperature $\left(T_{m}\right)$ from $>90^{\circ} \mathrm{C}$ (for PG4) to $46.2^{\circ} \mathrm{C}$ (for GV2) (Fig. S4). The addition of $50 \mathrm{~mol}$ equiv. of $\mathrm{A} / \mathrm{G}$ enhanced the stability of GVs to 54.0 or $56.7^{\circ} \mathrm{C}$, respectively (Fig. S4), which remained modest compared to the destabilization caused by GV sites to account for the restoration of G4-DNAzyme activity described above. We determined the dissociation constants $\left(K_{\mathrm{d}}\right)$ of hemin with GVs (red bars, Fig. 5), G4s (blue bars), and GVs in presence of increasing concentrations of A (green bars). $K_{\mathrm{d}}$ values were higher for GVs $(7.5-5.4 \mu \mathrm{M})$ than those for G4s (3.0-2.4 $\mu \mathrm{M})$, indicating that the affinity of hemin for an incomplete terminal G-quartet was weaker (Fig. S6 and Table S2). The partial restoration of a complete external G-quartet upon addition of A reinforced the hemin association (3.7-3.2 $\mu \mathrm{M})$, found close to that of the intact G4s. These results are fully consistent with the restoration of the G4-DNAzyme activity described above, and very significant differences $(p<0.001)$ between each group were verified by Student's $t$-tests (Fig. 5).

In summary, the results presented here demonstrate that the structural integrity of the 3'-end G-quartet is necessary for a G4 to be catalytically competent. The presence of a G-vacancy site not only decreases the stability of the G4 structure but also its hemin-binding affinity, which both concur in the overall lower catalytic performance. We also propose a way to remediate this loss via the addition of guanine surrogates prone to complete the G-vacancy site and restore the required structural integrity of the external G-quartet. The versatility of this approach was herein demonstrated via the restoration of the catalytic activity of both GVs and HGVs by the addition of A and G and that of G-triplex by the addition of TG3T. We also confirmed the positive contribution of the flanking nucleotides $\mathrm{dA}$ and dTC to the overall G4-DNAzyme properties of G4s, providing another way to enhance their catalytic properties. Interestingly, these improvements are efficient for parallel G4s only, which warrants further investigations to discover the actual G4-DNAzyme mechanisms. The results presented herein demonstrate the validity of G4s as promising and versatile biodevices.

\section{Electronic supporting information}

Supporting information is available in the online version of this article.

\section{References}

[1] R. R. Breaker, G. F. Joyce, Chem. Biol., 1994, 1, 223-229.

[2] Z. Li, C. Wang, J. Li, J. Zhang, C. Fan, I. Willner, H. Tian, CCS Chem., 2020, 2, 707-728.

[3] L. Liu, J. Lin, Y. Song, C. Yang, Z. Zhu, Chem. Res. Chin. Univ., 2020, $36,247-253$.

[4] S. K. Silverman, Trends Biochem. Sci., 2016, 41, 595-609.

[5] A. J. Boersma, R. P. Megens, B. L. Feringa, G. Roelfes, Chem. Soc. Rev., 2010, 39, 2083-2092.

[6] M. Cheng, Y. Li, J. Zhou, G. Jia, S. M. Lu, Y. Yang, C. Li, Chem. Commun., 2016, 52, 9644-9647.

[7] I. Willner, B. Shlyahovsky, M. Zayats, B. Willner, Chem. Soc. Rev., 2008, 37, 1153-1165.

[8] J. Liu, Z. Cao, Y. Lu, Chem. Rev., 2009, 109, 1948-1998.

[9] L. Ma, J. Liu, iScience, 2020, 23, 100815.

[10] J. H. Yum, S. Park, H. Sugiyama, Org. Biomol. Chem., 2019, 17, 9547-9561.

[11] J.-L. Mergny, D. Sen, Chem. Rev., 2019, 119, 6290-6325.

[12] P. Travascio, Y. Li, D. Sen, Chem. Biol., 1998, 5, 505-517.

[13] S. Nakayama, H. O. Sintim, Anal. Chim. Acta, 2012, 747, 1-6.

[14] L. Stefan, F. Denat, D. Monchaud, Nucleic Acids Res., 2012, 40, 8759-8772.

[15] D. Sen, L. C. H. Poon, Crit. Rev. Biochem. Mol. Biol., 2011, 46, 478-492.

[16] L. Stefan, F. Denat, D. Monchaud, J. Am. Chem. Soc., 2011, 133, 20405-20415.

[17] Q. Liu, H. Wang, X. Shi, Z. G. Wang, B. Ding, ACS Nano, 2017, 11, 7251-7258.

[18] W. Li, Y. Li, Z. Liu, B. Lin, H. Yi, F. Xu, Z. Nie, S. Yao, Nucleic Acids Res., 2016, 44, 7373-7384.

[19] J. Chen, Y. Guo, J. Zhou, H. Ju, Chem. Eur. J., 2017, 23, 4210-4215.

[20] T. Chang, H. Gong, P. Ding, X. Liu, W. Li, T. Bing, Z. Cao, D. Shangguan, Chem. Eur. J., 2016, 22, 4015-4021.

[21] J. Chen, Y. Zhang, M. Cheng, Y. Guo, J. Šponer, D. Monchaud, J.-L. Mergny, H. Ju, J. Zhou, ACS Catal., 2018, 8, 11352-11361.

[22] W. Li, S. Chen, D. Xu, Q. Wen, T. Yang, J. Liu, Chem. Eur. J., 2018, 24, 14500-14505.

[23] M. Cheng, J. Zhou, G. Jia, X. Ai, J.-L. Mergny, C. Li, Biochim. Biophys. 


\title{
Graphical Abstract
}

Chin. J. Catal., 2021, 42: 1102-1107 doi: 10.1016/S1872-2067(20)63744-5

The catalytic properties of DNA G-quadruplexes rely on their structural integrity

Jielin Chen, Mingpan Cheng, Jiawei Wang, Dehui Qiu, David Monchaud, Jean-Louis Mergny, Huangxian Ju *, Jun Zhou* Nanjing University, China; Université de Bourgogne, France; Institut Polytechnique de Paris, France

The catalytic properties of DNA G-quadruplex/hemin DNAzyme rely on its structural integrity, especially the 3'-end G-quartet, and completed via a "guanine surrogate insertion" strategy.

Acta, Gen. Subj., 2017, 1861, 1913-1920.

[24] E. Golub, H. B. Albada, W. C. Liao, Y. Biniuri, I. Willner, J. Am. Chem. Soc., 2016, 138, 164-172.

[25] J. Chen, J. Wang, S. C. C. van der Lubbe, M. Cheng, D. Qiu, D. Monchaud, J.-L. Mergny, C. F. Guerra, H. Ju, J. Zhou, CCS Chem., 2020, 2, 2183-2193.

[26] N. Shumayrikh, Y. C. Huang, D. Sen, Nucleic Acids Res., 2015, 43, 4191-4201.

[27] P. Travascio, P. K. Witting, A. G. Mauk, D. Sen, J. Am. Chem. Soc., 2001, 123, 1337-1348.

[28] R. Shinomiya, Y. Katahira, H. Araki, T. Shibata, A. Momotake, S. Yanagisawa, T. Ogura, A. Suzuki, S. Neya, Y. Yamamoto, Biochemistry, 2018, 57, 5930-5937.

[29] Y. Yamamoto, H. Araki, R. Shinomiya, K. Hayasaka, Y. Nakayama, K. Ochi, T. Shibata, A. Momotake, T. Ohyama, M. Hagihara, H. Hemmi, Biochemistry, 2018, 57, 5938-5948.

[30] I. Ourliac-Garnier, M. A. Elizondo-Riojas, S. Redon, N. P. Farrell, S. Bombard, Biochemistry, 2005, 44, 10620-10634.

[31] H. Bertrand, S. Bombard, D. Monchaud, M. P. Teulade-Fichou, J. Biol. Inorg. Chem., 2007, 12, 1003-1014.

[32] P. Stadlbauer, M. Krepl, T. E. Cheatham, 3rd, J. Koca, J. Šponer, Nucleic Acids Res., 2013, 41, 7128-7143.
[33] J. Wang, M. Cheng, J. Chen, H. Ju, D. Monchaud, J.-L. Mergny, J. Zhou, Chem. Commun., 2020, 56, 1839-1842.

[34] B. Heddi, N. Martin-Pintado, Z. Serimbetov, T. M. A. Kari, A. T. Phan, Nucleic Acids Res., 2016, 44, 910-916.

[35] K. B. Wang, J. Dickerhoff, G. Wu, D. Yang, J. Am. Chem. Soc., 2020, 142, 5204-5211.

[36] F. R. Winnerdy, P. Das, B. Heddi, A. T. Phan, J. Am. Chem. Soc., 2019, 141, 18038-18047.

[37] Y. Guo, J. Chen, M. Cheng, D. Monchaud, J. Zhou, H. Ju, Angew. Chem. Int. Ed., 2017, 56, 16636-16640.

[38] X. M. Li, K. W. Zheng, Y. H. Hao, Z. Tan, Angew. Chem. Int. Ed., 2016, 55, 13759-13764.

[39] Y. D. He, K. W. Zheng, C. J. Wen, X. M. Li, J. Y. Gong, Y. H. Hao, Y. Zhao, Z. Tan, J. Am. Chem. Soc., 2020, 142, 11394-11403.

[40] D. J. Y. Tan, P. Das, F. R. Winnerdy, K. W. Lim, A. T. Phan, Chem. Commun., 2020, 56, 5897-5900.

[41] S. Wang, B. Fu, S. Peng, X. Zhang, T. Tian, X. Zhou, Chem. Commun., 2013, 49, 7920-7922.

[42] N. Zhang, A. T. Phan, D. J. Patel, J. Am. Chem. Soc., 2005, 127, 17277-17285.

[43] O. Lustgarten, R. Carmieli, L. Motiei, D. Margulies, Angew. Chem. Int. Ed., 2019, 58, 184-188.

\section{DNA G-四链体的结构完整性对催化性质的影响}

\author{
陈杰林 ${ }^{\mathrm{a}, \dagger}$ ，程明攀 ${ }^{\mathrm{a}, \dagger}$ ，王佳伟 ${ }^{\mathrm{a}}$ ，仇得辉 ${ }^{\mathrm{a}}$, David Monchaud ${ }^{\mathrm{b}}$, Jean-Louis Mergny ${ }^{\mathrm{a}, \mathrm{c}}$, \\ 鞠熀先 ${ }^{\mathrm{a},}$, 周 俊 $\mathrm{a}$, \\ a南京大学化学化工学院, 生命分析化学国家重点实验室, 江苏南京210023, 中国 \\ b勃艮第大学分子化学研究所, CNRS UMR6302, 第戎 21000 , 法国 \\ ${ }^{\mathrm{C}}$ 巴黎综合理工学院, 光学与生物科学实验室, CNRS, INSERM, 帕莱索 91128 , 法国
}

摘要: DNA酶中的G-四链体-血红素(G4-hemin)DNA酶结构具有较高的设计性和化学稳定性, 因此格外受研究者关注. G平面作为辅酶因子 hemin的结合位点, 不仅提供大 $\pi$ 平面与hemin结合, 而且其平面上的 $\mathrm{G}$ 碱基还可以充当近端配位基团与 hemin进行配位. 因此, 研究G-平面完整性在G4-DNA酶体系中的作用具有重要意义. 本文设计了一系列含有空位的 G4(G-vacancy, GV)及G-三链体, 通过“鸟嘌呤类似物插入”策略实现G-平面完整性以及DNA酶催化活性的恢复. 结果表明, 末端G-平面完整性是G4-DNA酶具有催化活性的必要条件, 且其能够充当近端配位基团与末端碱基协同激活G4-DNA酶.

考虑到hemin会选择性地结合于 G4的3'-端平面, 本文以含有 3 '-端空位的G4以及 G-三链体为模型进行DNA酶的构建. 结果表明,相较于末端完整的G4-hemin DNA酶, 未端不完整的G4结构所形成的DNA酶催化活性很低. 为了进一步验证该 
平面完整性的重要性, 本文提出了“鸟嘌呤衍生物插入”策略, 即将鸟嘌呤衍生物(无环鸟苷和鸟苷)插入G-空位以恢复G-平 面的完整性. 通过圆二色光谱和紫外熔解实验, 发现末端平面完整性的缺失会使圆二色特征峰信号和 G4结构热稳定性下 降, 而鸟嘌呤碱基类似物的加入则可以使特征峰信号以及热稳定性得到一定程度的恢复, 表明鸟嘌呤碱基类似物的加入确 实使G-平面完整性得到恢复. 与此同时, 随着鸟嘌呤碱基类似物浓度的增加, G4-hemin DNA酶活性逐渐增强, 最终恢复至 与完整 $\mathrm{G} 4$ 一样的活性. 在以 $\mathrm{G}$-三链体为模型的实验中, 本文通过另一条富 $\mathrm{G}$ 序列与 $\mathrm{G}$-三链体进行结合, 形成复合的 $(3+1)$ 型 G4结构, 最终实现了DNA酶活性的恢复. 同时, 在 3'-G-平面末端增加了激活碱基(dA或dTC), 结果表明, 即使G-平面不完 整, 末端碱基依旧能够激活DNA酶, 但酶活性整体弱于完整G4时的活性. 同样, “鸟嘌呤衍生物插入”策略可以使酶活性得 到恢复.

本文系列实验充分说明了末端碱基可与G-平面形成协同作用, 与hemin的铁中心共同形成六配位关系, 加速催化中间 体生成, 进而增强催化活性. 有趣的是, 通过设计Holliday junction结构研究发现, “鸟嘌呤衍生物插入”策略仅适用于平行 G4结构. G-空位的存在不仅降低了 G4结构的稳定性, 而且降低了其与hemin间的亲和力, 二者均是造成G4-DNA酶催化能 力下降的主要因素. 总之, 本文证明了 3'-端G-平面的完整性是G4-DNA酶实现其催化能力必不可少的因素, 对理解末端G平面在G4-DNA酶中的作用具有重要的参考意义.

关键词: G-四链体; G-四链体DNA酶; G-空位; G-平面完整性; 鸟嘌呤衍生物

收稿日期: 2020-10-10. 接受日期: 2020-11-11. 上网时间: 2021-03-05.

*通讯联系人. 电子信箱: hxju@nju.edu.cn

\#通讯联系人. 电子信箱: jun.zhou@nju.edu.cn

†共同第一作者.

基金来源：国家自然科学基金(21977045, 21635005); 中央高校基本科研业务费(02051430210); 南京大学高层次人才科研启动经 费(020514912216).

本文的电子版全文由Elsevier出版社在ScienceDirect上出版(http://www.sciencedirect.com/journal/chinese-journal-of-catalysis). 